\title{
Painéis de formatura do acervo do Museu da Escola Catarinense: um arquivo aberto $^{1}$
}

\section{Graduation panels of the Museu da Escola Catarinense collection: an open file}

\author{
Sandra Makowiecky \\ Doutora em Ciências Humanas pela Universidade Federal de Santa Catarina (UFSC). Professora da Universidade do \\ Estado de Santa Catarina (Udesc) - sandra.makowiecky@gmail.com - http://orcid.org/0000-0002-9132-3643 \\ Beatriz Goudard \\ Doutora em Engenharia Civil pela Universidade Federal de Santa Catarina (UFSC). Professora da Universidade do \\ Estado de Santa Catarina (Udesc) - beatriz.goudard@udesc.br - http://orcid.org/0000-0002-5182-7871
}

\section{Resumo}

Relata a preservação de um patrimônio cultural catarinense ligado à Educação e que se constitui em fonte de pesquisa, pois se tratam de materiais que não estão restritos aos suportes tradicionais de documentação histórica, mas estão repletos de histórias para contar. O problema central deste trabalho é apresentar um processo de documentação inicial de recuperação dos painéis, indicando caminhos de pesquisa em aberto, a partir de uma pesquisa básica, bibliográfica e documental. Os painéis de Formatura do acervo do Museu da Escola Catarinense constituem arquivos recentemente recuperados, que contribuirão para a História da Educação em Santa Catarina, mesmo sendo considerados como fontes acessórias, possuem capacidade de contribuir para configurar a cultura e descrever subjacentes lógicas institucionais.

Palavras-chave: Painéis de Formatura. Museu da Escola Catarinense. Arquivo aberto. História da Educação em Santa Catarina.

\begin{abstract}
It reports the preservation of a Santa Catarina cultural heritage linked to Education, which is also a source of research, as they are materials that are not restricted to the traditional supports of historical documentation, but are full of stories to be told. The main problem of this paper is to present an initial documentation recovery process of the panels, indicating open research paths, from a basic bibliographic and documentary research. The Graduation panels of the Santa Catarina School Museum collection constitute recently recovered archives, which will contribute to the History of Education in Santa Catarina, which, even being considered as ancillary sources, have the capacity to contribute to configure the culture and to describe the underlying institutional logic.
\end{abstract}

Keywords: Graduation panels. Santa Catarina's School Museum. An open file. History of education in Santa Catarina's state.

Recebido em: 25/05/2018

Aceito em: 26/07/2019

\footnotetext{
${ }^{1}$ Uma versão sintética desse trabalho foi apresentada no VIII Seminário do Museu D. Joao VI/ IV Colóquio Internacional Coleções de Arte em Portugal e Brasil nos séculos XIX e XX, com o subtítulo temático - Arte e seus lugares: Coleções em espaços reais. Rio de Janeiro, EBA/ UFRJ, no MNBA, 2017, com o título Painéis de Formatura no acervo Museu da Escola Catarinense: uma visão do avesso.
} 


\section{INTRODUÇÃO}

O Museu da Escola Catarinense - MESC - (criado em 1992) está localizado em edifício que foi construído para abrigar a Escola Normal Catharinense (1892 - 1926), em Florianópolis. Trata-se de um edifício tombado como Patrimônio Histórico e é um monumento que permeia a história da Educação em Santa Catarina. O MESC tem como objetivo principal sua consolidação como espaço educativo não formal, responsável pela preservação do patrimônio cultural catarinense ligado à Educação. Integra oficialmente os Sistemas Nacional e Estadual de Museus e possui inscrição no Instituto Brasileiro de Museus (IBRAM). Apresenta salas de exposição de caráter permanente, todas de conteúdo didático e pedagógico, com acervo de móveis, livros, brinquedos. Nas paredes é possível vislumbrarmos uma tradição perdida com os anos: os quadros/painéis de formatura. No século passado era costume que cada turma depois de formada deixasse de recordação para a instituição, um quadro com fotografias dos alunos, mestres e homenageados.

Como problemática, entendemos que História das Instituições Escolares é entendida com base em Werle (2004), como uma representação da escola expressa sob a forma de síntese narrativa construída a partir da análise de documentos. As fontes para a realização da história de instituições escolares são de variados tipos, registros que podem ser utilizados como indícios de tal história. A história institucional da Academia do Comércio pode ser analisada a partir dos quadros que agrupam fotografias de várias pessoas que marcaram, em conjunto, a vida da escola. Os quadros de formatura e as fotografias dos formandos são representações de momentos da história institucional e como documentos que atestam seu projeto formativo: a conclusão do curso em sua solenidade de formatura.

Como hipótese, podemos dizer que os quadros de formatura são polissêmicos e ambíguos e indicam sentidos que os mesmos podem tomar frente às instituições escolares, procedendo à contextualização da imagem, atribuição e detalhamento de significados e que mesmo sendo considerados como fontes acessórias, possuem capacidade de contribuir para configurar a cultura e descrever subjacentes lógicas institucionais. 
Os quadros que retratavam os alunos da Escola Normal e Instituto Dias Velho ${ }^{2}$ se perderam no tempo, mas no Museu são apresentados outros quadros contemporâneos àqueles, que pertenceram à extinta Academia de Comércio de Santa Catarina e foram recuperados pela equipe técnica do MESC e por profissionais de restauração (Figura 1). Todavia, a Figura 2 apresenta uma imagem do painel da primeira turma do curso de "Administração e Finanças", de 1945, para ilustrar de forma mais visível, o estado de degradação dos painéis.

O objetivo deste artigo é relatarmos a preservação de um patrimônio cultural catarinense ligado à Educação e que se constitui também em fonte documental, pois se tratam de documentos que não estão restritos aos suportes tradicionais de documentação histórica, mas estão repletos de histórias para contar. Os painéis de formatura do acervo do Museu da Escola Catarinense constituem arquivos recentemente recuperados, mas com muito futuro pela frente

Trata-se de uma história a qual a exibição dos quadros na parede não nos permite perceber. Procedeu-se ao recomendado em laudo exarado por especialista, ao recuperar o acervo que constitui registro importante da memória de catarinenses com formação escolar na Academia do Comércio. Foram recuperados os 13 painéis recebidos (Figura 3), dos quais dois estavam praticamente destruídos, os de 1946 e 1949 (Figura 5). Este trabalho, apresenta várias problemáticas com as quais nossos museus se defrontam, tanto por dificuldades operacionais e financeiras, quanto por falta de investimentos e equipes especializadas. Com certeza, se constitui em material farto para pesquisas posteriores, como um arquivo à espera se sua redenção. Jacques Derrida, em "Pensar em não ver: escritos sobre as artes do visível" (2012), discute arquivo entendendo a memória como a necessidade ou desejo de colecionismo. Temos a necessidade de memória, porque temos o medo de perder. Para Derrida (2012, p. 132), “O arquivo, não é uma questão de passado, é uma questão de futuro", pois selecionamos o que consideramos importante e o que precisamos que se repita no futuro.

\footnotetext{
${ }^{2} \mathrm{O}$ edifício do atual Museu da Escola Catarinense foi construído para abrigar a Escola Normal Catharinense, no final do século XIX (1892) e inaugurada no prédio do MESC em 1926. Neste momento foi implantado um plano urbanístico para a cidade de Florianópolis que compreendia além do edifício sede da Escola, a ponte Hercílio Luz, ligação com o continente, o Palácio Cruz e Souza, palácio do governo entre outros. Em 1935, a Escola Normal Catharinense passa a ser o Colégio de Educação. Este foi na realidade uma continuação da Escola Normal Catharinense e originou-se de uma reforma no sistema de ensino. Em 1947, passa a se chamar Colégio Estadual Dias Velho. No início da década de 1960 inicia-se a obra do atual prédio do Colégio, localizado na Avenida Mauro Ramos, e em 1963, deixou o prédio da Rua Saldanha Marinho para transferir-se para as modernas e amplas instalações na Avenida, cujas obras duraram mais de 10 anos. Finalmente em 1969, o Colégio passou a chamar-se definitivamente Instituto Estadual de Educação (SANTA CATARINA, 2014).
} 
Figura 1- Treze painéis em estado original, antes de recuperação. 0 estado de degradação dos mesmos não é plenamente perceptível em imagem de pequena dimensão. O painel de 1947 aparece em frente e em verso.

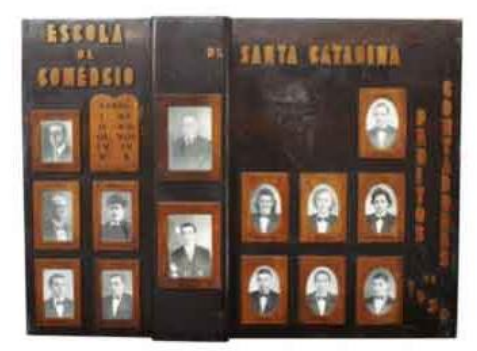

Peritos Contadores da Escola de Comércio de Santa Catarina - 1938

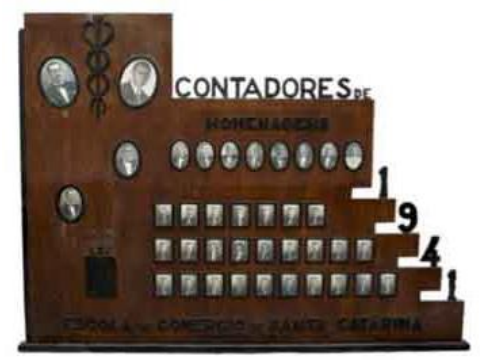

Contadores da Escola de Comércio de Santa Catarina (Instituto Livre) - 1941

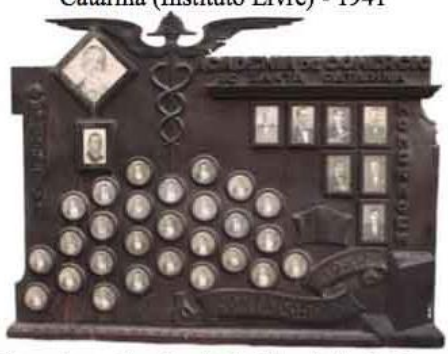

Contadores Academia de Comércio de Santa Catarina - 1944

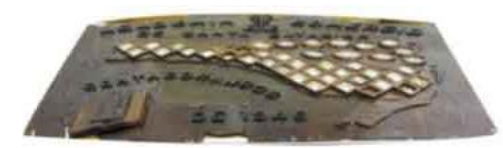

Contadores Academia de Comércio de Santa Catarina - 1946

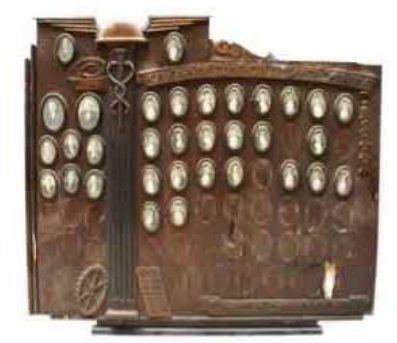

Técnicos em Contabilidade Academia de Comércio de Santa Catarina - 1949

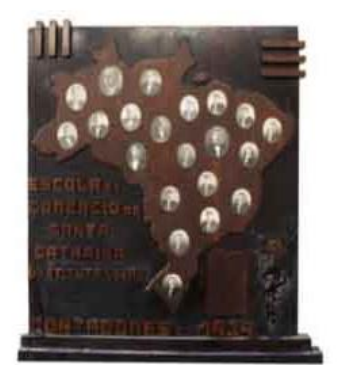

Contadores da Escola de Comércio de Santa Catarina (Instituto Livre) - 1939

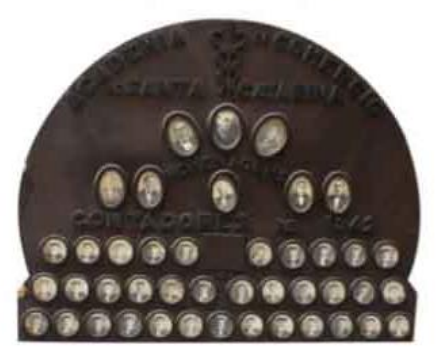

Contadores Academia de Comércio de Santa Catarina - 1942

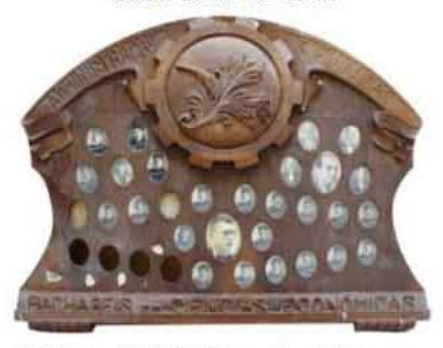
$1^{\text {a }}$ Turma de Administração e Finanças -
Bachareis em Ciências Econômicas - 1945

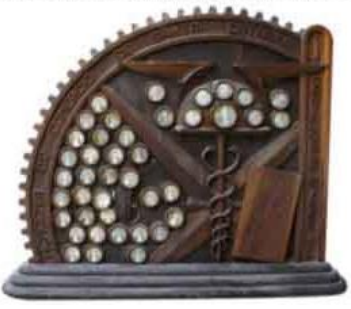

Contadores Academia de Comércio de Santa Catarina - 1947

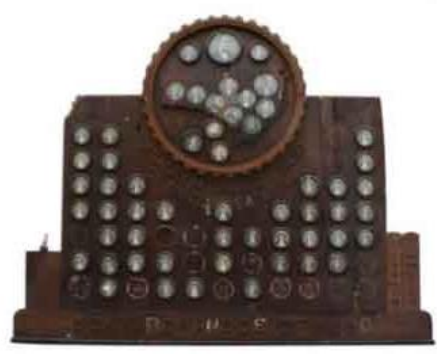

Contadorandos Academia de Comércio de Santa Catarina - 1950

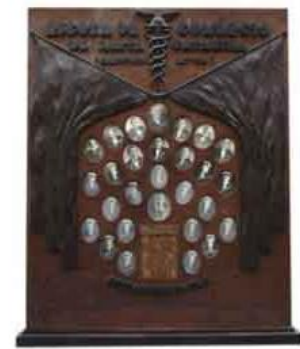

Contadores da Escola de Comércio de Santa Catarina (Instituto Livre) - 1940

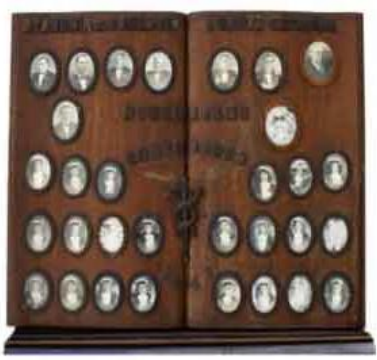

Contadores Academia de Comércio de Santa Catarina - 1943

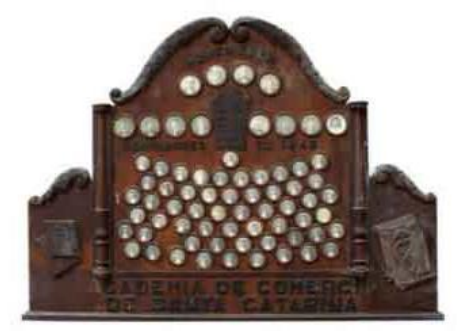

Contadores Academia de Comércio de Santa Catarina - 1945

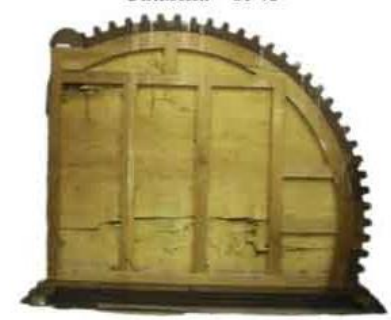

Fonte: Acervo MESC. Fotos das autoras (2012). 
Figura 2 - Painel do Curso de Administração e Finanças, turma de 1945.

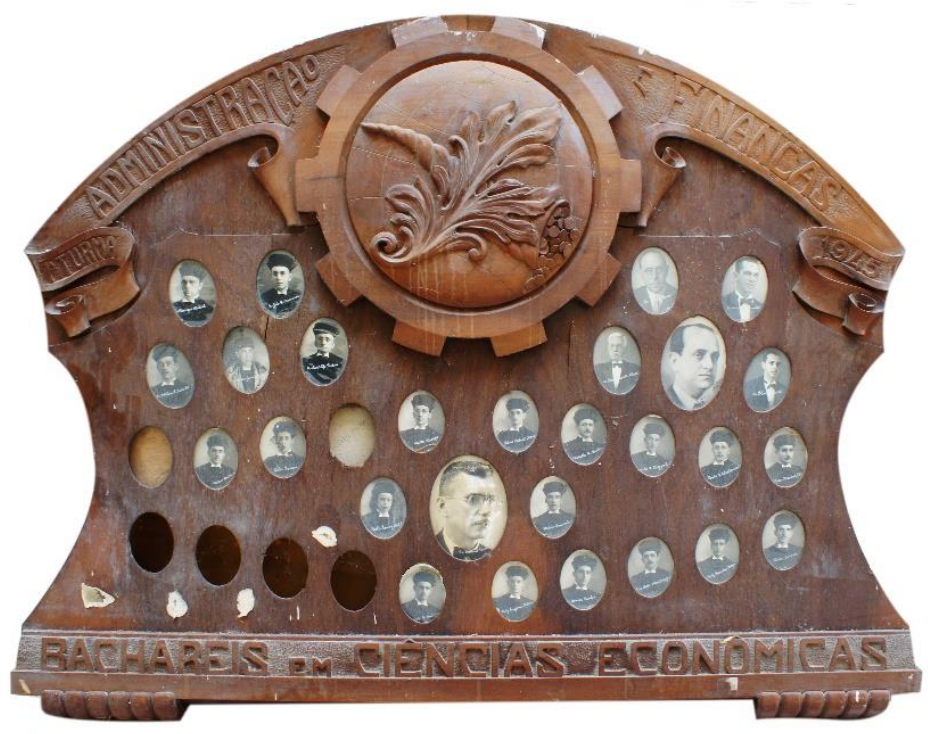

Fonte: Acervo MESC. Fotos das autoras (2012).

"É o que fazemos todo o tempo na vida, a pulsão de arquivo: o que vamos deixar de lado e o que vamos repetir?" (DERRIDA, 2012, p. 132). O papel do arquivista, além de guardar é também o de destruir, pois se ele guardasse tudo, não seria um arquivo. Para o autor, esquecer é preferir não guardar. O arquivista faz uma escolha. A memória no arquivo está em trazer para a atualidade o que está distante e dar continuidade ao passado garantindo que este sobreviva amanhã. Este movimento de olhar projetado para o passado é expresso por Giorgio Agamben em "O que é contemporâneo?", no livro "O que é contemporâneo e outros ensaios", quando diz que a "via de acesso ao presente tem necessariamente a forma de uma arqueologia" (AGAMBEN, 2009, p. 70), no sentido de situações já acontecidas e vividas e no presente não podemos mais viver nem alcançar, mas devemos lançar um olhar para o não vivido no que é vivido, em um movimento que não cessa em se repetir. 
Painéis de formatura do acervo do Museu da Escola Catarinense: um arquivo aberto

Sandra Makowiecky

Figura 3 - Treze Painéis após a recuperação. A figura apresenta o painel de 1946 em processo de recuperação, finalizado em 2018.

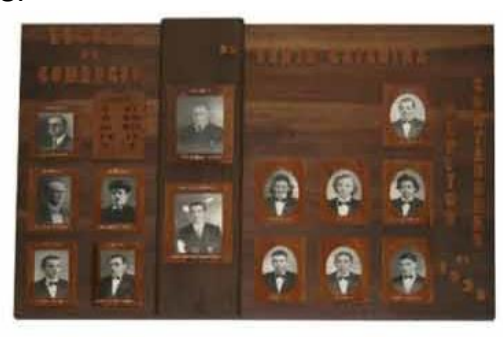

Peritos Contadores da Escola de Comércio de Santa Catarina - 1938

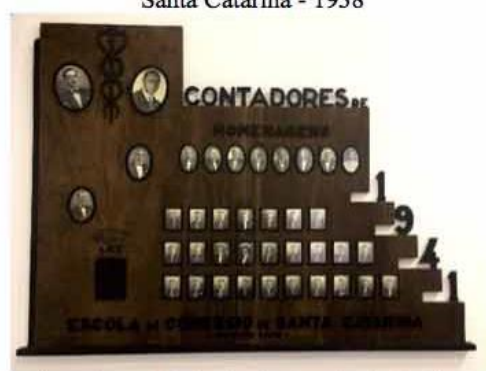

Contadores da Escola de Comércio de Santa Catarina (Instituto Livre) - 1941

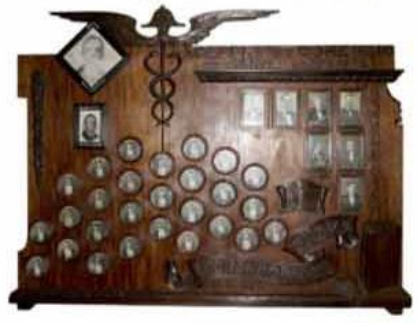

Contadores Academia de Comércio de Santa Catarina - 1944

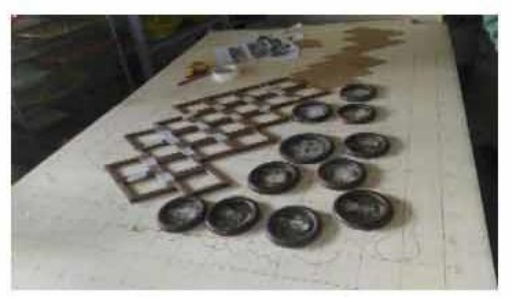

Contadores Academia de Comércio de Santa Catarina - 1946

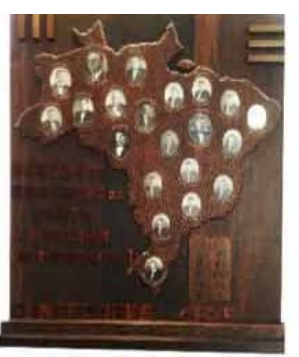

Contadores da Escola de Comércio de Santa Catarina (Instituto Livre) - 1939

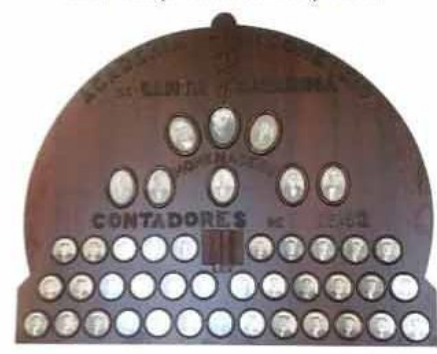

Contadores Academia de Comércio de Santa Catarina - 1942

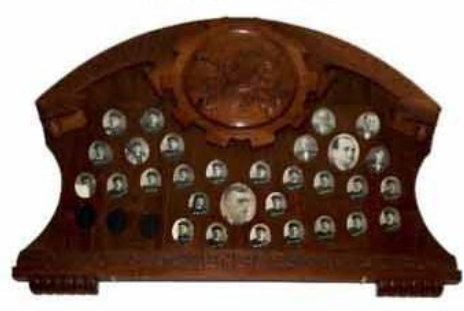

$1^{\text {a }}$ Turma de Administração e Finanças Bachareis em Ciências Econômicas - 1945

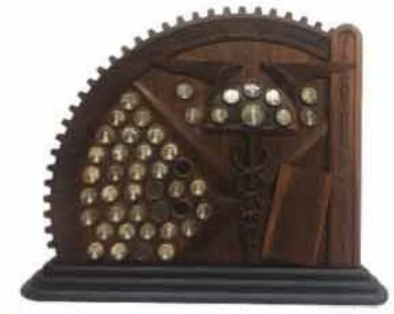

Contadores Academia de Comércio de Santa Catarina - 1947

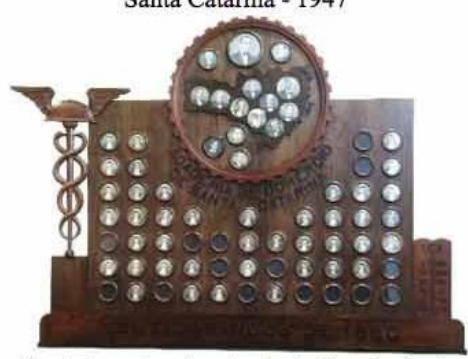

Contadorandos Academia de Comércio de Santa Catarina - 1950

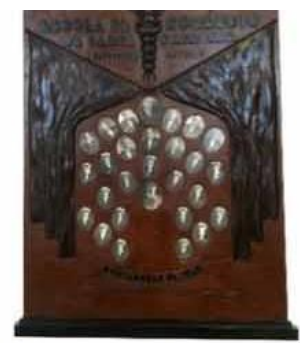

Contadores da Escola de Comércio de Santa Catarina (Instituto Livre) - 1940

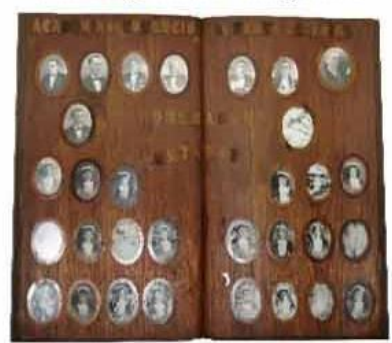

Contadores Academia de Comércio de Santa

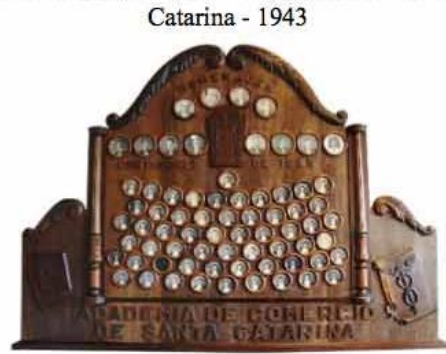

Contadores Academia de Comércio de Santa Catarina - 1945

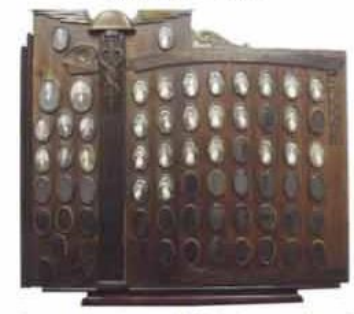

Técnicos em Contabilidade Academia de Comércio de Santa Catarina - 1949

Fonte: Acervo MESC. Fotos das autoras (2017). 
Figura 4 - Acima, painéis de 1946 e 1949 (aqueles em estado de degradação mais adiantado), antes da recuperação. Abaixo, após a recuperação finalizada em 2018.
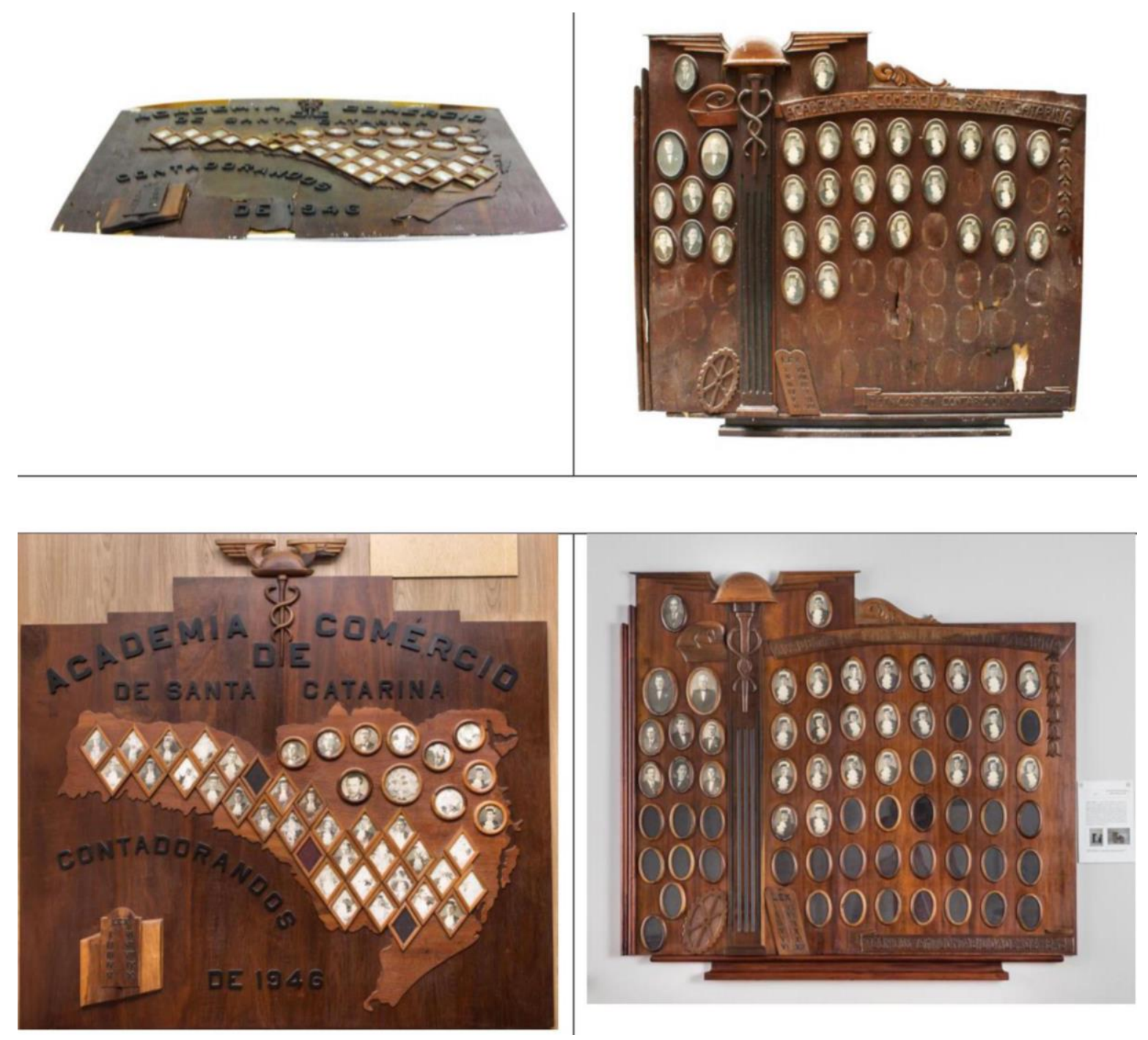

Fonte: Acervo MESC. Fotos das autoras (2017) e Carlos Pontalti (2019).

\section{ACADEMIA DE COMÉRCIO DE SANTA CATARINA}

Petry (2013), Faria, Santos e Valle (2014), Sanson e Nicolau (2006), e Vieira (1986) descrevem a história que reproduzimos sinteticamente. Em Florianópolis, as primeiras tentativas de criar um estabelecimento de nível superior datam do início do século XX. No governo de Vidal Ramos o ensino público catarinense foi reestruturado e, nesta campanha de reforma pedagógica, a Escola Normal foi o primeiro estabelecimento de ensino a ser reformulado. Até então as unidades escolares mais destacadas em Florianópolis eram o colégio Coração de Jesus, o Ginásio Catarinense, a Escola Normal e o liceu de Artes e Ofícios. Após completar o curso ginasial, os alunos não tinham 
perspectivas de continuidade nos estudos dentro da capital, ingressando então nas atividades profissionais, ou, poucos, que se dirigiam a centros maiores, dedicavam-se a algum curso superior. Desta carência educacional surgiu a intenção de implantar um estabelecimento de ensino superior na capital. Foi então criado o Instituto Politécnico, a princípio sem sede própria, funcionando num sobrado alugado situado à rua João Pinto, no 411, de propriedade do Liceu de Artes e Ofícios. “O Instituto Politécnico de Florianópolis foi a primeira instituição de ensino superior do Estado de Santa Catarina, sua fundação data de 13 de março de 1917, sob a liderança de José Arthur Boiteux" ${ }^{\prime \prime}$, considerado o patriarca do ensino superior no Estado, e era uma instituição privada que dependia, em parte, de subsídio público. "Durante sua existência ofereceu diversos cursos, dentre eles, os de Odontologia, Farmácia, Engenharia (Geologia), Veterinária, Botânica, Agrimensura e Topografia"4 "Desde o início oferecia também cursos de técnicas comerciais: o preparatório, com dois anos, e o de especialização, com três anos" (VIEIRA, 1986, p. 51). Infelizmente, esses cursos não atraíram estudantes dos melhores colégios, em geral filhos das famílias mais ricas, que preferiam uma formação que os levasse às áreas tradicionais, tais como Direito, Medicina e Engenharia, na época só era possível fora do Estado. A demanda foi fraca também por parte dos estudantes de menor renda ou que trabalhavam, apesar de os cursos serem noturnos. $O$ Instituto Politécnico era submetido à fiscalização federal e estadual.

Até 1922, a diretoria do Instituto dedicou-se à implantação de diversos cursos e à instalação das unidades pedagógicas necessárias. Neste período o governador Hercílio Luz cedeu a área de terra para a construção do prédio próprio do Instituto. Foi aberta concorrência para confecção da planta, feito o orçamento do novo edifício e lançada a sua pedra fundamental, acontecimento solene ocorrido no dia da comemoração do centenário da independência do Brasil.

Em 1923 o Instituto Politécnico foi reconhecido como de utilidade pública, por meio de decreto federal. O governo liberou verba para a construção do seu prédio em um terreno situado na avenida Hercílio luz, antiga avenida do saneamento, entre as ruas Nunes Machado e General Bittencourt. Além do auxílio financeiro dos governos Federal e Estadual, o Ministério da Agricultura, banqueiros, industriais e comerciantes catarinenses doaram diversos materiais para a construção do prédio, num terreno de $720 \mathrm{~m}^{2}$, com uma área edificada de $682 \mathrm{~m}^{2}$, o que constituía na época,

\footnotetext{
${ }^{3}$ CENTRO DE CIÊNCIAS JURÍDICAS, [201-].

${ }^{4}$ Idem, op.cit.
} 
depois do prédio da Escola Normal, o maior prédio da cidade de Florianópolis (onde hoje funciona o Museu da Escola Catarinense). A transferência dos alunos para seu prédio definitivo ocorreu entre 1924 e 1925. Em 1926, 1928 e 1929 surgiram novas questões sobre a condução das obras do prédio, referindo-se às instalações de água, luz, esgoto, pintura e acabamentos, o que dificulta datar a sua exata conclusão. "Os cursos de técnicas comerciais do Instituto, segundo as evidências disponíveis, formaram a última turma em 1930, tendo sido a primeira das quatro áreas a fechar" (VIEIRA, 1986, p. 62).

Com a morte de Boiteux, em 1934, o instituto encerrou suas atividades no ano seguinte, e em 1935, foi extinto o Instituto Politécnico. Ao encerrar seus últimos cursos, o Instituto tecnológico foi absorvido pela Escola Prática de Comércio em meados de 1934/35. O prédio passou a abrigar a Escola do Comércio de Santa Catarina, subordinada ao então Departamento de Educação. A Instituição foi criada pelo Decreto Estadual no 782 de 5 de abril de 1935 que previu a adoção do Instituto Politécnico pelo Estado, tendo este ficado com a incumbência de manter o curso de Comércio. Mesmo tendo sido criada por força de Decreto Estadual, em 1935, a Academia de Comércio, a partir de 1938, retornou à condição de sociedade civil sem fins lucrativos. Foi por iniciativa de professores do Instituto Tecnológico que surgiu a Faculdade de Direito de Santa Catarina, cujo funcionamento começou em 1932. Essa faculdade, no entanto, teve suas primeiras aulas em outro prédio do centro da cidade, junto à Praça XV. E ali, no primeiro dia letivo do novo curso, foi proferida pelo Prof. Henrique da Silva Fontes a primeira aula catarinense de Economia em nível superior. A disciplina era Economia Política e Ciências das Finanças. Desta forma, o Instituto Politécnico foi a primeira instituição universitária do Estado, precursora da Faculdade de Direito (1932), que foi a semente da UFSC, no final da década de 1950. Em 18/12/1960, foi uma das faculdades fundadoras da Universidade de Santa Catarina, atual UFSC (Lei $n^{\circ} 3.849 / 60$ ), de onde saiu também, o Curso de Economia. Muitos dos alunos que fizeram curso superior na Academia de Comércio, também continuaram seus estudos na UFSC, em especial em Direito.

Esse curso era ainda do tipo misto, mas surgiu na época em que se discutia, no Brasil, a separação entre Economia e Contabilidade. A reforma de 1945 as separou ${ }^{5}$. Isso transformou o

\footnotetext{
${ }^{5} \mathrm{Em}$ 1931, o decreto 20158 organizou o ensino comercial e regulamentou a profissão contábil. Em 1940, o decreto 2 627 constituiu-se na primeira Lei das Sociedades por Ações do país. Em 1945, a profissão contábil foi considerada carreira universitária. Em 1946, foram criados o Conselho Federal de Contabilidade e os conselhos regionais de
} 
Curso Superior - que estava em processo de reconhecimento oficial junto ao Ministério da Educação - no Curso de Ciências Econômicas da Faculdade de Ciências Econômicas. O Curso Superior de Administração e Finanças, que concedia o diploma de Bacharel em Ciências Econômicas, foi criado em Florianópolis pela Academia de Comércio no mês de agosto de 1942 e começou a funcionar no início do ano letivo de 1943, com uma turma de cinco alunos. Era uma instituição mantida por uma associação, mas sustentada pelo governo, que financiava as bolsas de estudos dos alunos. A Portaria no 512 de 11/12/1945 (do Diretor Geral do Departamento Nacional de Educação) alterou sua denominação para Curso de Ciências Econômicas. O curso recebeu reconhecimento oficial pelo Decreto Federal 37.994/55. Seu corpo docente foi inicialmente formado por alguns professores catedráticos da Academia de Comércio. Foram também expedidos convites a professores da Faculdade de Direito de Santa Catarina para regência de outras cadeiras. A Academia de Comércio de Santa Catarina era mantida basicamente por subvenções do governo do Estado e por taxas de matrícula e mensalidades dos alunos. A Academia enfrentou problemas financeiros para manter o novo curso, que só não foi interrompido em 1950 porque professores concordaram em lecionar gratuitamente naquele ano. Nos anos seguintes, o orçamento da Academia voltou a equilibrar-se, principalmente a partir de 1954, quando o professor Elpídio Barbosa, nome de projeção junto ao governo estadual, assumiu a direção da Faculdade. A partir de 1958, a Faculdade passou a receber subvenção federal e em 1959 obteve do governo do Estado dez apólices inalienáveis no valor de 10 milhões de cruzeiros, que the renderiam juros de 5\% a.a. 0 governo estadual também lhe cedeu para uso o prédio da Travessa Ratcliff, no centro de Florianópolis. Nesse mesmo ano, a partir de 09 de dezembro, com as novas fontes de recursos e o novo prédio, a Faculdade de Ciências Econômicas tornou-se independente da Academia de Comércio.

A Academia de Comércio de Santa Catarina funcionou no prédio até a década de 1990, quando foi extinta. Em 2010, foram inauguradas as obras de restauração da edificação, em um ato onde foi sancionada a lei que autoriza a cessão e o uso do imóvel pelo Instituto Histórico e Geográfico de Santa Catarina e da Academia Catarinense de Letras, duas instituições também fundadas por José Arthur Boiteux, sendo que o prédio recebeu a denominação de Casa José A. 
Boiteux, em merecido reconhecimento. José A. Boiteux, nascido em Tijucas, em 1865, foi jornalista, deputado, historiador e advogado. Sua participação na vida intelectual foi constante, nos deixando extenso legado.

Este relato sobre a Academia do Comércio tem por objetivo realçarmos a importância desta Instituição na formação de catarinenses ilustres e na vocação do ensino superior da llha de Santa Catarina, o que irá reforçar a importância da preservação dos painéis. Pelas fotos e nomes constantes nos painéis percebemos de imediato nomes de homens e mulheres que participaram ativamente da construção de uma sociedade mais representativa, sobretudo na produção e transmissão de conhecimento, como professores, reitores, advogados, prefeitos, administradores públicos, entre tantos outros. Nomes que fizeram a história do Estado de Santa Catarina. Personalidades que saíram mais fortes dos processos educacionais, reinventando as regras de convívio para além dos interesses meramente personalistas e individualizantes, ou das práticas da omissão e da indiferença. Essas histórias precisam ser revistas, necessitando pesquisas sobre cada painel. Quando da recuperação dos painéis, muitos destes nomes já estavam apagados pelo tempo, ou irreconhecíveis. No final do ano de 2017, a equipe do Museu recebeu uma pasta em que constava, entre outros documentos, o livro de atas com documentação das formaturas a que se referem os painéis. Em um golpe de sorte ou destino, tal material veio como transferência do arquivo do Centro de Ciências da Educação da UDESC para o Museu da Escola Catarinense. Para a equipe do museu, este era um material perdido. Assim, tanto a documentação em formato de painéis e a documentação formal, com livro de atas, nominatas de todos as personalidades que constam dos painéis e respectivas assinaturas estão agora completos. Prontos para serem descortinados.

\section{PAINÉIS DE FORMATURA/QUADROS DE FORMATURA}

Como sabemos, no século passado era costume que cada turma depois de formada deixasse de recordação para a instituição um quadro com fotografias dos alunos, mestres e homenageados. Infelizmente, quase desapareceu um dos mais importantes registros históricos de nossas escolas: o quadro de formatura. No passado, eram verdadeiras relíquias, feitos por artesãos reconhecidos, peças que enobreciam escolas e faziam parte da história dos formandos. 
Podemos dizer que são verdadeiros monumentos, obras comemorativas ou uma recordação importante a ser perpetuada, um sinal do passado. Na conceituação de Le Goff (1990, p. 536) "O monumento tem como características o ligar-se ao poder de perpetuação, voluntária ou involuntária, das sociedades históricas (é um legado à memória coletiva) e o reenviar a testemunhos que só numa parcela mínima são testemunhos escritos". Segundo Werle (2006), os quadros de formatura são monumentos que comemoram a conclusão do curso, perpetuam a memória do acontecimento e do grupo, são uma forma específica do mesmo grupo estar e apropriar-se da instituição escolar - dimensão pessoal/grupal de sucesso -, proclamam a presença institucional na memória coletiva e o sucesso da escola no alcance de seus objetivos e missão pedagógica -, dimensão institucional de sucesso. Apresentam um significado social afirmativo para a escola e para o grupo de alunos formados.

Até os colégios tinham e preservavam os quadros de formatura. Além de contribuição histórica como registro de alunos, são peças de artesania primorosa. Ainda não encontramos registros sobre a confecção destes quadros no acervo do Museu da Escola Catarinense. Se era um artesão individual que os fazia, se era uma empresa contratada, pois existiam empresas que realizavam este trabalho, nem mesmo se eram feitos em Santa Catarina. Mistos de álbum fotográfico e artesanato, os quadros de formatura podem ser analisados sob diversas perspectivas. Uma delas trata de objetos pertencentes ao acervo da cultura material escolar, na concepção proposta por Souza (2007), que permite compreender esses objetos como documentos de investigação histórica, que possibilitam tanto a análise de sua materialidade quanto das relações intrínsecas provocadas pelos usos, por suas compreensões, pelo registro da história. De acordo com Souza (2007, p. 170), a cultura material escolar é composta por:

\footnotetext{
[...] artefatos e contextos materiais relacionados à educação escolarizada, a expressão não apenas amplia o seu significado reinserindo as edificações, mobiliário, os materiais didáticos, os recursos audiovisuais, e até mesmo as chamadas novas tecnologias do ensino, como também remete à intrínseca relação que os objetos guardam com a produção de sentidos e com a problemática da produção e reprodução social.
}

Dessa forma, os quadros de formatura da Academia do Comércio de Santa Catarina podem ser entendidos como objetos componentes da cultura material do lugar, os quais guardam em sua materialidade a capacidade de perenizar rituais, saberes e práticas na passagem do tempo e fornecem elementos para o estudo e compreensão da sociedade da época. 
Alguns destes quadros de formatura eram mais simples, com moldura, fotografias e desenhos. Outros, extremamente elaborados, como os do acervo do Museu, confeccionados em madeira maciça, de grandes proporções (Figura 5).

A análise desses artefatos, onde predominam imagens fotográficas, os concebe como suportes de marcas que podem revelar nuances do investimento político, institucional e pessoal engendrados pela efervescência da construção social de necessidades e crenças na formação através da educação. São componentes de uma trama de relações da tessitura social constituída por seus produtores e consumidores que, em contato com eles, deram sentido mútuo às suas existências no universo de uma escola pulsante, de saberes e práticas vividas, sentidos e reproduzidos (COELHO JUNIOR, 2013). Muito há que se pesquisar nestes arquivos de futuro em aberto. Neste trabalho, trataremos de outra coisa: a pulsão de morte, vista por seu avesso. Estes painéis e sua história nos remetem de imediato à pulsão de morte a que se refere Derrida, em "Mal de arquivo", uma pulsão de agressão e de destruição que impele ao esquecimento, à amnésia, à aniquilação da memória.

A pulsão de morte é acima de tudo, anarquívica [...] sempre foi, por vocação, silenciosa, destruidora do arquivo. A pulsão de morte é também uma pulsão de agressão e de destruição, ela leva não somente ao esquecimento, à amnésia, à aniquilação da memória como mneme ou anamnesis, mas comanda também o apagamento radical, na verdade a erradicação daquilo que não se reduz jamais à mneme ou à anamnesis; a saber, o arquivo, a consignação, o dispositivo documental ou monumental (DERRIDA, 2001, p. 21-22).

Como evitamos a morte desses painéis? Em sendo salvos, para que poderão ser úteis? Em texto muito elucidativo de Werle (2006), denominado: “Ancorando quadros de formatura na história institucional", podemos ampliar o conhecimento sobre estes objetos. A autora se refere a quadros mais simples e também aos painéis mais complexos, como os do Museu da Escola (Figura $5)$. 
Figura 5 - Vista geral da sala expositiva, onde os painéis estão expostos como acervo.

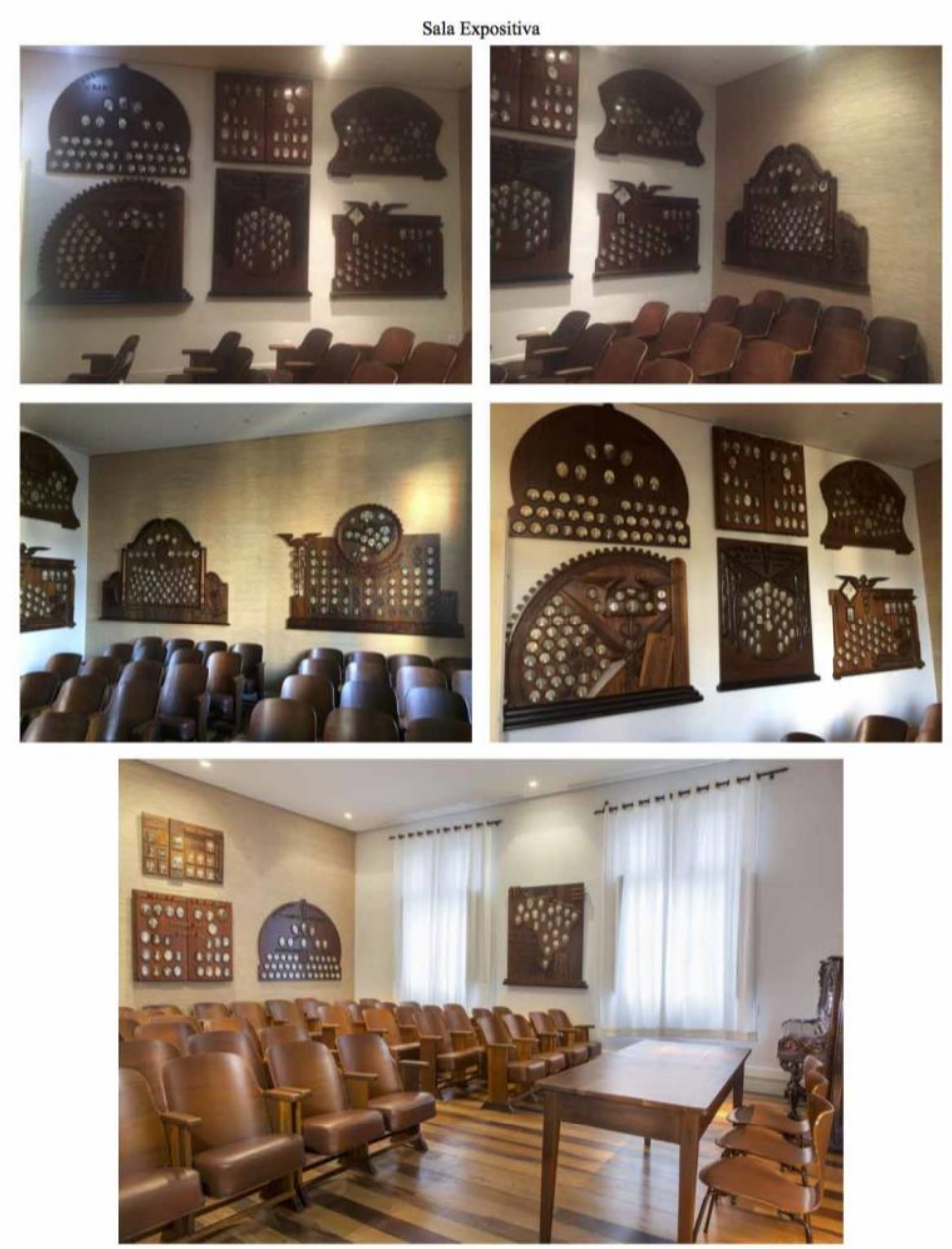

Fonte: Acervo MESC. Fotos das autoras (2017).

Iremos nos deter nestes, utilizando as descrições do texto. Diz a autora, que os quadros de formatura não são apenas fotografias de um conjunto de formandos, mas fotografias de um grupo de alunas (os), concluintes de um curso, identificados individualmente, organizados numa totalidade - o quadro - referidas ao momento histórico e às propostas da escola, tendo como finalidade colocar-se como conjunto articulado, em exposição, nas dependências da escola. As fotografias em suas propriedades - papel plano, em preto e branco - nas quais as pessoas fotografadas - alunos, homenageados, paraninfo - são representados em face e busto, homogeneizados pela iluminação, dimensão, formato - geralmente ovais - pela vestimenta e pela posição, são articuladas, superando a redução aos indivíduos representados em cada uma delas isoladamente, rearticuladas num todo: o quadro de formatura. Tais quadros (início do século XX) 
são peças grandes - alguns com dois metros de altura -, agregando fotografias sustentadas em madeira pintada ou esculpida em relevo. Quando feitos de variados tipos de madeira, exploram, esteticamente, texturas e tons de espécies diferentes. Não apenas esculturas, mas dizeres compõem a estética dos quadros de formatura. Os elementos escritos são identificadores da instituição escolar, da cidade em que a escola se situa, do ano de conclusão, e sempre trazem o nome completo dos alunos, alguns mencionam a cidade de origem, bem como dos professores homenageados e paraninfo, ancorando as imagens no social, no institucional, no tempo e no espaço. Os quadros de formatura dão visibilidade às pessoas que passaram pela escola e ao acontecimento de sua formatura, adornam os corredores da escola e são uma peça apreciável, digna de ser guardada. Eles são um objeto cultural que tem uma intenção determinada: celebrar um fato notável, não cotidiano - a conclusão de um curso -, festejado como uma solenidade - a formatura marcada com vestes não usuais, postura estudada -, importante de ser lembrada. Os quadros de formatura hierarquizam. Alunos são homogeneizados em roupas, cabelos e poses, bem como na regularidade com que as fotos são distribuídas no conjunto do quadro. Em separado, e em fotos de maiores dimensões do que as dos alunos, estão homenageados e paraninfo, figuras ilustres, por isto, maiores, distintas e articuladas, como grupo, em espaço diferente do de alunos. Não há mulheres paraninfando turmas de formandos, ou seja, o lugar de patrono ou protetor de turma estava, na época, reservado a homens, enfatizando, portanto, uma tradição do início do século XX e que perdurou, ao menos no âmbito deste estudo, do ano de 1938 até o último quadro de formatura, no ano de 1950. Os quadros de formatura, na época em que foram construídos eram expostos em salas de visitas, em salões reservados para solenidades, em corredores. No Museu, encontram-se na sala Euterpe, constituindo parte do acervo museológico, em uma ideia de imersão (figura 3), derivado do latim immersio, sinônimo de mergulho, que significa possibilitar a introdução dos visitantes do museu num determinado ambiente, seja este real ou imaginário. Tais quadros e sua exposição pública explicitam redes de relacionamento pessoal e a importância institucional. Todavia, como enfatizado no título deste trabalho, "Painéis de formatura do acervo do Museu da Escola Catarinense: um arquivo aberto", falta-nos apresentar dados concretos a partir da análise dos quadros. O texto apresenta uma reflexão sobre o potencial informativo dos quadros, mas não avança em relação à leitura dessas obras, justamente por se tratar de uma pesquisa em estágio inicial. 


\section{OS SÍMBOLOS UTILIZADOS NOS PAINÉIS}

Os painéis de formatura também contextualizam valores de época. Observamos pelo texto de Werle (2006) que era muito comum a decoração dos quadros/painéis com esculturas que lembram instrumentos de estudo e leitura - mapa mundi, mapa do Brasil, mapas dos estados, das cidades, esquadro, pergaminho, compasso, livros - elementos cívicos - bandeira dos Estados e do Brasil, escudo nacional, pira da pátria, entre outros - e religiosos - imagem de santos, Nossa Senhora e Cristo (Figura 6), que podem ser considerados como instrumentos de afirmação de determinadas identidades. De maneira geral, apresentam uma aparência ordenada, sóbria e coerente. Identificam-se como elementos contextualizadores, ao lado da moldura e suas esculturas, os lemas inscritos nos quadros e a indumentária dos fotografados. As vestimentas também formam padrões. Chapéus, paletó e gravata, no mais das vezes com outras questões definidas entre os formandos. As fotos de professores homenageados e paraninfos não mantêm um único formato como as dos formandos (as), que olham para um mesmo lugar, inclinam a cabeça uniformemente $\mathrm{e}$ transmitem, em seu conjunto, um significado de alinhamento disciplinado.

Outros elementos comuns são os lemas, um preceito escrito, uma sentença. Os lemas dos quadros de formatura são breves afirmativas escritas em latim ou português. Um bastante significativo no painel de 1945 (Figura 7) da academia do Comércio é: "Labor Omnia Vincit"- "O trabalho vence tudo", fragmento de versos de Virgílio, os quais se tornaram proverbiais.

Outro elemento bastante presente é o Caduceu de Mercúrio, insígnia do Deus do Comércio. O Caduceu é um bastão (poder, que no caso tem por objeto o patrimônio de quaisquer entidades), entrelaçado com duas serpentes (sabedoria, isto é, quando se deve estudar antes de agir, para escolher o caminho correto), tendo na parte superior duas pequenas asas (diligências, ou seja, a presteza, a solicitude, a dedicação e o cuidado no exercer da profissão) e um elmo alado (pensamentos elevados, uma peça de armadura antiga que cobria a cabeça, tem significado de proteção contra ações desonestas), o qual é um dos atributos do deus Mercúrio (Hermes), protetor do comércio, emblema da paz e prosperidade. Os livros, muito comuns, adequados para a nutrição do espírito e da mente. A roda da Fortuna, presente no painel de 1949, uma roda com seis raios, indica destino, reflexão, em que tudo acontece a seu tempo, fazendo lembrar da garantia de cumprimento de um destino, representado pela lei de causa e efeito e também pela lei da compensação. Fortuna quer dizer sorte, destino e não fortuna material. 
Figura 6 - Símbolos presentes na ornamentação - flores, caduceu, lex com doze leis, lemas em latim, fotografias, livros, mapa de Santa Catarina.
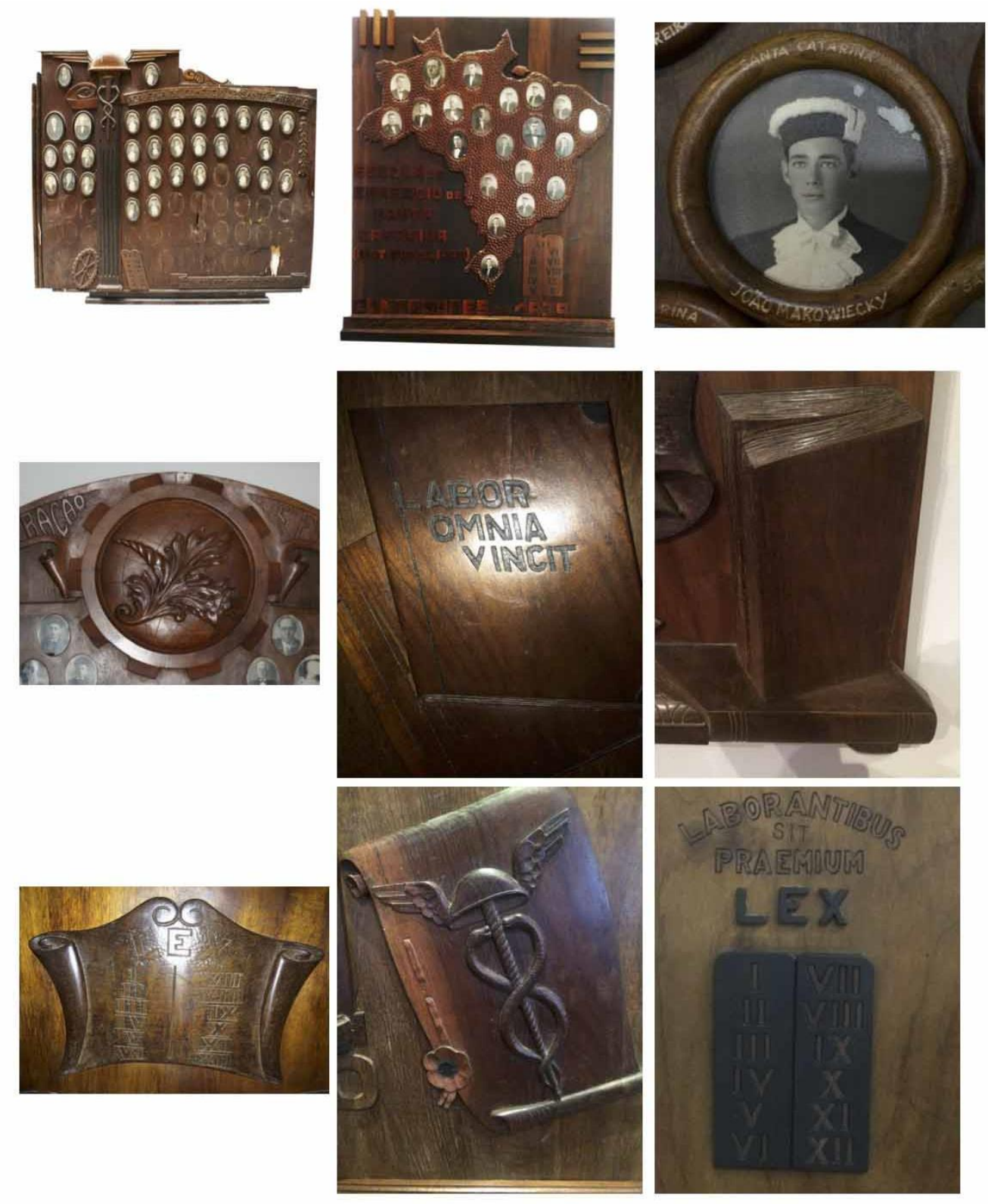

Fonte: Acervo MESC. Fotos das autoras (2017). 
Figura 7 - Detalhe do Painel de 1945 da academia do Comércio é: "Labor Omnia Vincit" - "O trabalho vence tudo".

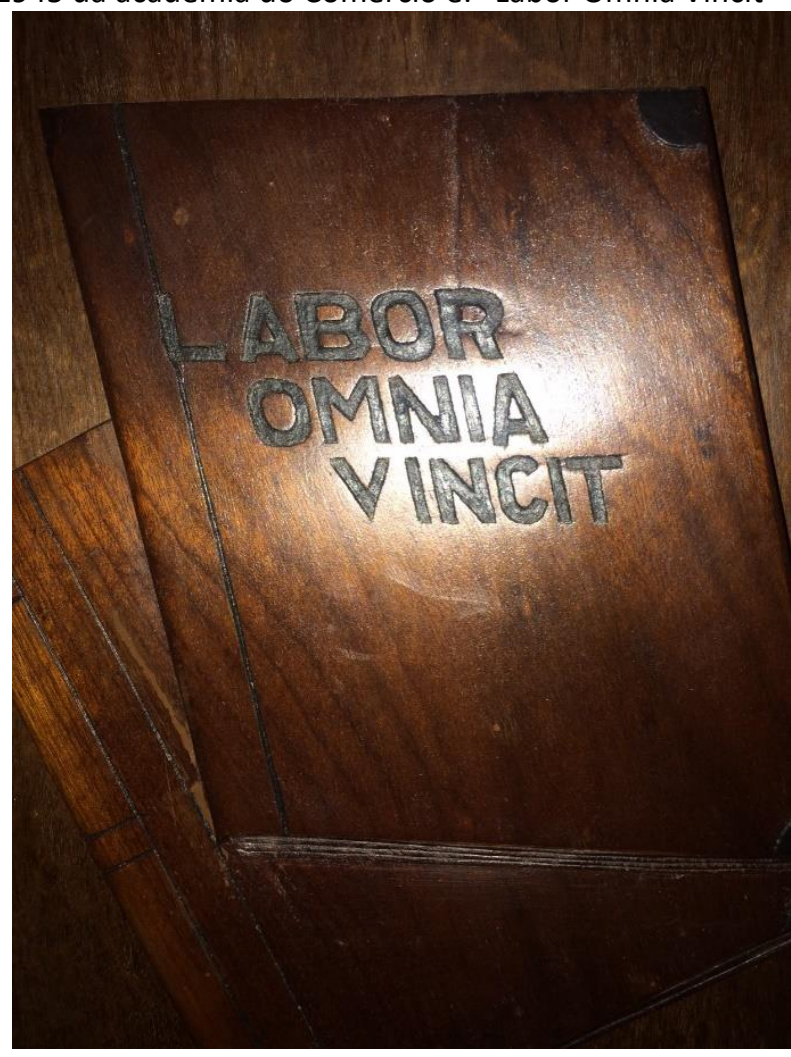

Fonte: Acervo MESC. Fotos das autoras (2017).

No painel de 1945 (Figura 2), "Administração e Finanças", encontramos uma cornucópia, antigo símbolo da abundância e que simboliza agricultura e comércio. Outro símbolo recorrente são as Tábuas da Lei com a legenda "LEX", advindas da antiga tradição judaica, de que a lei foi entregue por Deus a Moisés em tábuas, contendo os Dez Mandamentos. No caso, mencionam 12 leis. Há cinco focos temáticos predominantes nos lemas dos quadros de formatura, conforme o caso: religião, ascese, sucesso, civismo e ciência ${ }^{6}$.

O mapa do Brasil (Figura 12), elementos da Cidade de Florianópolis, como a Ponte Hercílio Luz (Figura 11) também aparecem. Os lemas compunham, com as esculturas dos quadros, um contexto simbólico modelar para os (as) formandos (as), alinhados com as propostas formativas da instituição. Um lema inscrito num quadro de formatura, sempre exposto à vista, tem um impacto mais permanente, como que relembrando seu conteúdo constantemente. Por outro lado, pela perspectiva de inspirador do futuro e da vida profissional, os lemas comprometiam os diplomados,

\footnotetext{
${ }^{6}$ Ascese é uma ideia que se estabelece na relação com sucesso e religião.
} 
não apenas no momento da formatura, mas, enquanto o quadro se mantivesse exposto na escola, ele estava a relembrar o compromisso assumido no momento da diplomação. Ou seja, um lema como inspirador, impõe demonstração na vida prática.

\section{UMA BREVE DESCRIÇÃO DO PROCESSO DE RECUPERAÇÃO DOS PAINÉIS DA ACADEMIA DE COMÉRCIO}

Os painéis que pertenceram à extinta Academia de Comércio de Santa Catarina foram doados ao MESC em 2005, ficando por 7 anos, praticamente abandonados, sem cuidados especiais, sem tratamento contra insetos, cupins e até receberam água da chuva durante reforma do telhado do museu, o que danificou muitas das fotografias dos formandos. A recuperação pela equipe técnica do MESC, com pesquisa, sistematização e guarda do material, iniciou no ano de 2013, e na parte de recomposição técnica, por Cassiano Reinaldin e por Dario Luciano de Aguiar e Emília Aguiar, entre os anos de 2015, 2016 e 2017. Não se sabe em que estado de conservação chegaram ao MESC, mas com certeza já estavam infectados por xilófagos. As fotos mostram o estado de decomposição no qual foram encontrados os painéis, os quais aos poucos foram recuperados (Figura 8). 
Painéis de formatura do acervo do Museu da Escola Catarinense: um arquivo aberto Sandra Makowiecky

Figura 8 - Estado dos painéis antes da recuperação. No chão, madeira em pó, deteriorada por cupins.
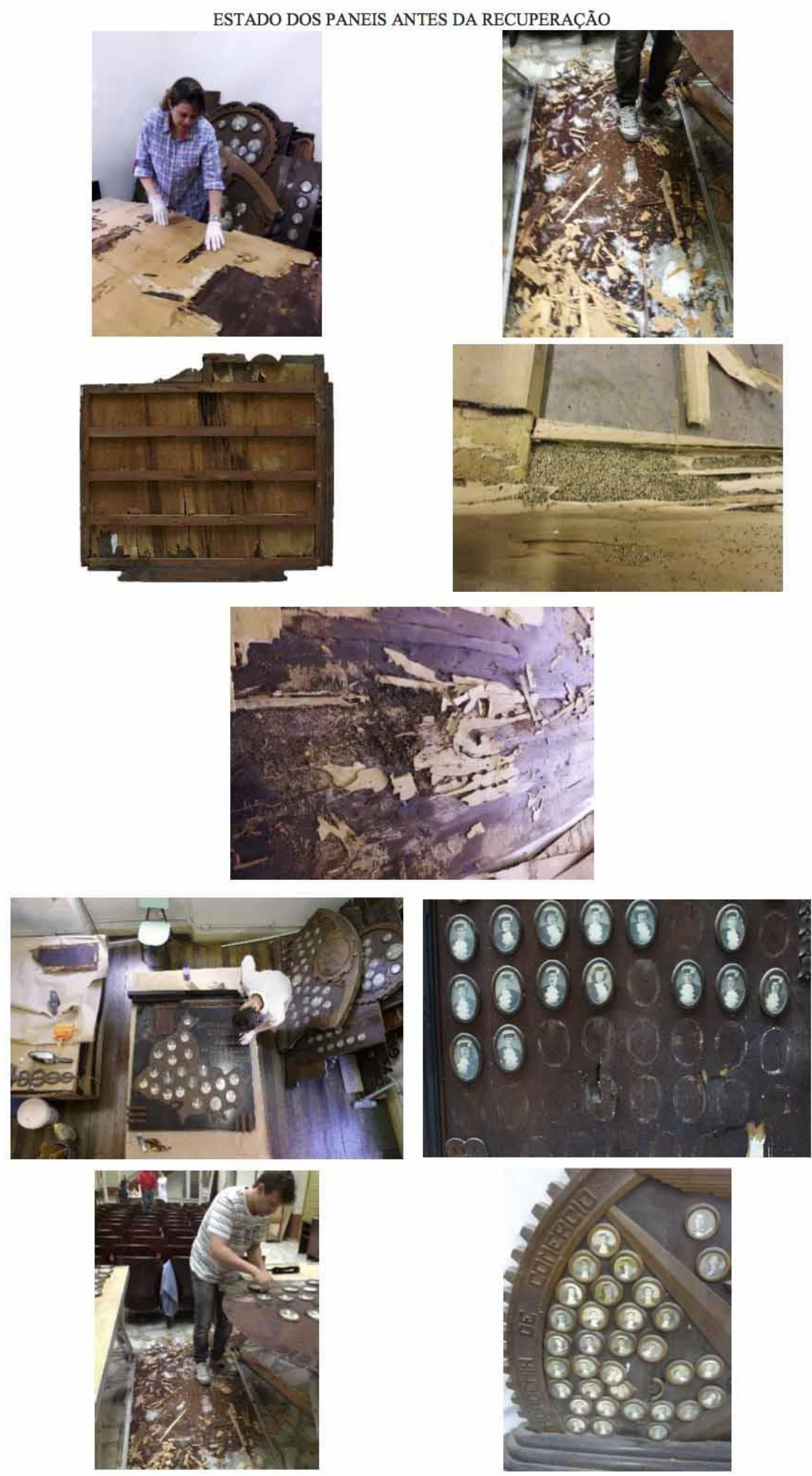

Fonte: Acervo MESC. Fotos das autoras (2013). 
O Laudo do Estado de Conservação dos painéis em madeira e composição fotográfica da Escola do Comércio - Florianópolis, realizado em 2013, por Márcia Regina Escorteganha, Conservadora-Restauradora da Fundação Catarinense de Cultura, atestava seu estado de degradação geral. Após o laudo, a equipe do Museu procedeu ao recomendado e hoje o acervo conta com 13 painéis, bem como fotografias, constituintes de um registro importantíssimo da memória de catarinenses que tiveram sua formação escolar na Academia do Comércio. O Laudo recomendava a retirada urgente do suporte secundário, dizendo que a medida era necessária por se tratar somente de um suporte de sustentação que não afetaria a estruturação nem a estética da obra em si. Informava também sobre o estado de degradação avançado e a infestação por insetos xilófagos generalizada, o que tornava inviável sua conservação. Portanto, deveria ser descartado para não contaminar o restante do acervo e nem mesmo as estruturas arquitetônicas do Museu Escola Catarinense. Esta retirada deveria ser efetuada por um profissional conservador e com os devidos cuidados em manter intacta a estrutura original do suporte principal. Indicava formas de armazenamento dos elementos dos painéis, das fotografias, em que as áreas em desprendimento deveriam ser acondicionadas e agrupadas em dossiês relativos a cada painel, e fornecia instruções para sua remontagem posterior, indicando realizar um registro fotográfico detalhado e descritivo de cada um dos painéis (Figura 9). A tarefa foi empreendida, com realização moldes em papelão, fotografias e diversas anotações sobre as imagens e sua localização. Tal cuidado permitiu sua recomposição.

Em 3 painéis, a saber 1938, 1939 e 1943, os suportes secundários originais foram mantidos, bem como os ornamentos originais. Em outros 9 painéis, a saber 1940, 1941, 1942, 1944, 1945 (Figura 10), 1945 - adm. e finanças -, 1947, 1949, 1950, os suportes originais foram descartados e foram criados novos suportes secundários, mantendo ornamentos originais, bem como reposição de ornamentos faltantes, através de recuperação cuidadosa e atenta aos detalhes, usando também chapas que reproduzem a madeira da época de criação desses quadros de formatura. Dois dos painéis, 1946 e 1949, estavam praticamente destruídos por insetos xilófagos e foram refeitos através de registros fotográficos, mantendo e mesclando os ornamentos e letras originais e recuperadas, quando possível. Do painel de 1946, praticamente tudo precisou ser refeito, era o mais danificado. Os 13 painéis foram recuperados. Para que esses painéis 
continuassem a existir, muitas batalhas foram travadas, desde o convencimento dentro da Universidade para contratar especialistas para sua reconstituição, procurando soluções dentro das leis de licitação, até admitir que a própria Universidade deixou este material se deteriorar por um bom tempo.

Figura 9 - Detalhes das etapas do processo de desmonte e acomodação das peças para armazenamento, no aguardo da recuperação.

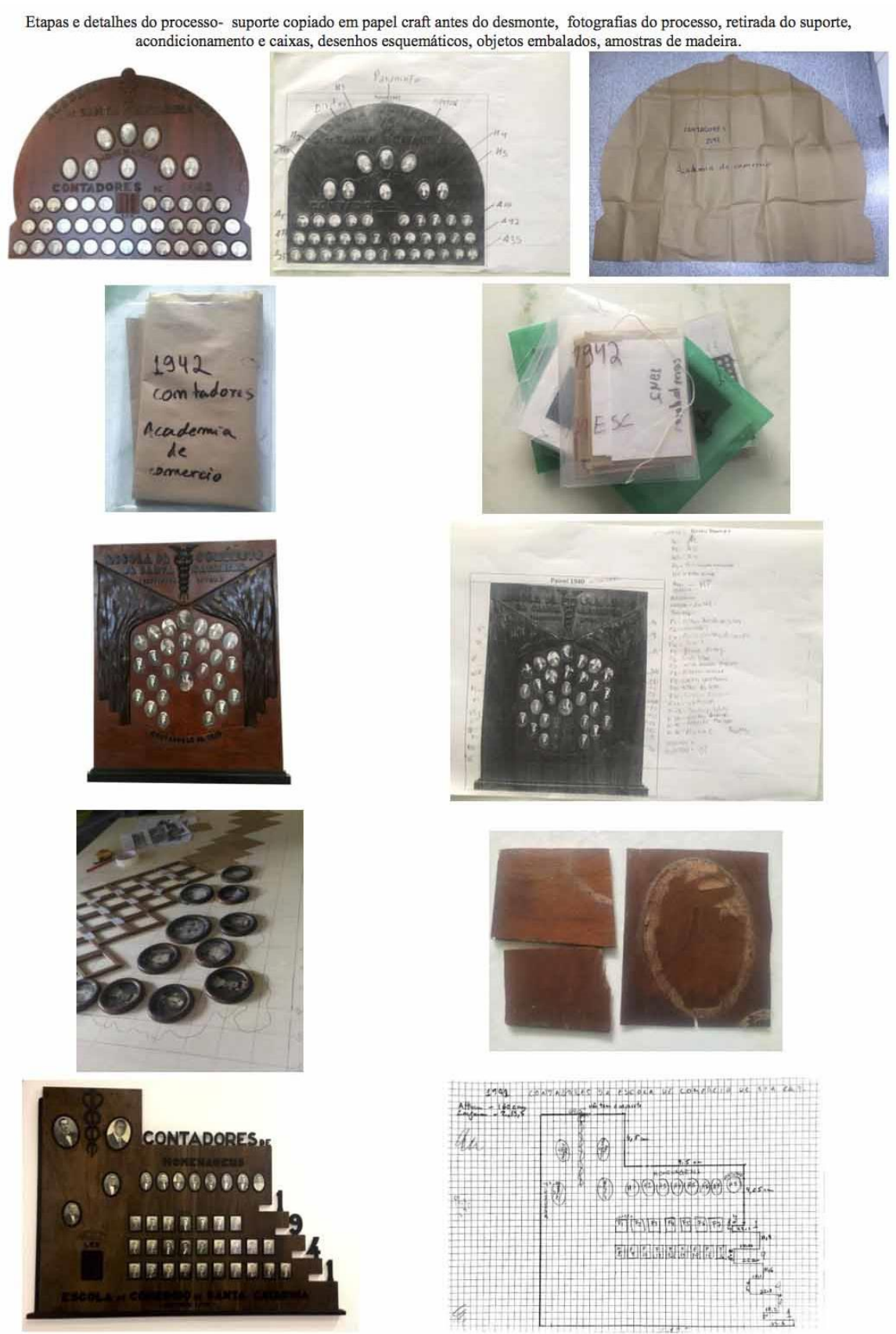

Fonte: Acervo MESC. Fotos das autoras (2013). 
De 2005 a 2012 eles ficaram acomodados em uma sala, sem o cuidado necessário, sendo que neste período os cupins continuaram em sua ação frenética a devorar a madeira. Por conta de uma reforma no telhado do Museu alguns painéis receberam água da chuva, o que estragou muitas das fotos, em um final de semana sem assistência alguma, acrescido do fato de que estavam completamente desprotegidos. Ressalta-se que, apesar de possuírem uma avaliação técnica e contar com ajuda de conservadora em orientação para desmonte, a equipe atuante no trabalho não tem formação na área. Este foi feito com intuição, planejamento, sentido de organização e muito cuidado. Em 2017 e em 2018, este acervo e seu trabalho de recuperação, concorreu ao Prêmio Rodrigo Melo Andrade Franco de Andrade, o qual prestigia as ações de preservação do patrimônio cultural brasileiro, por Santa Catarina. ${ }^{7}$

Figura 10 - Painel Contadores - Turma de 1945.

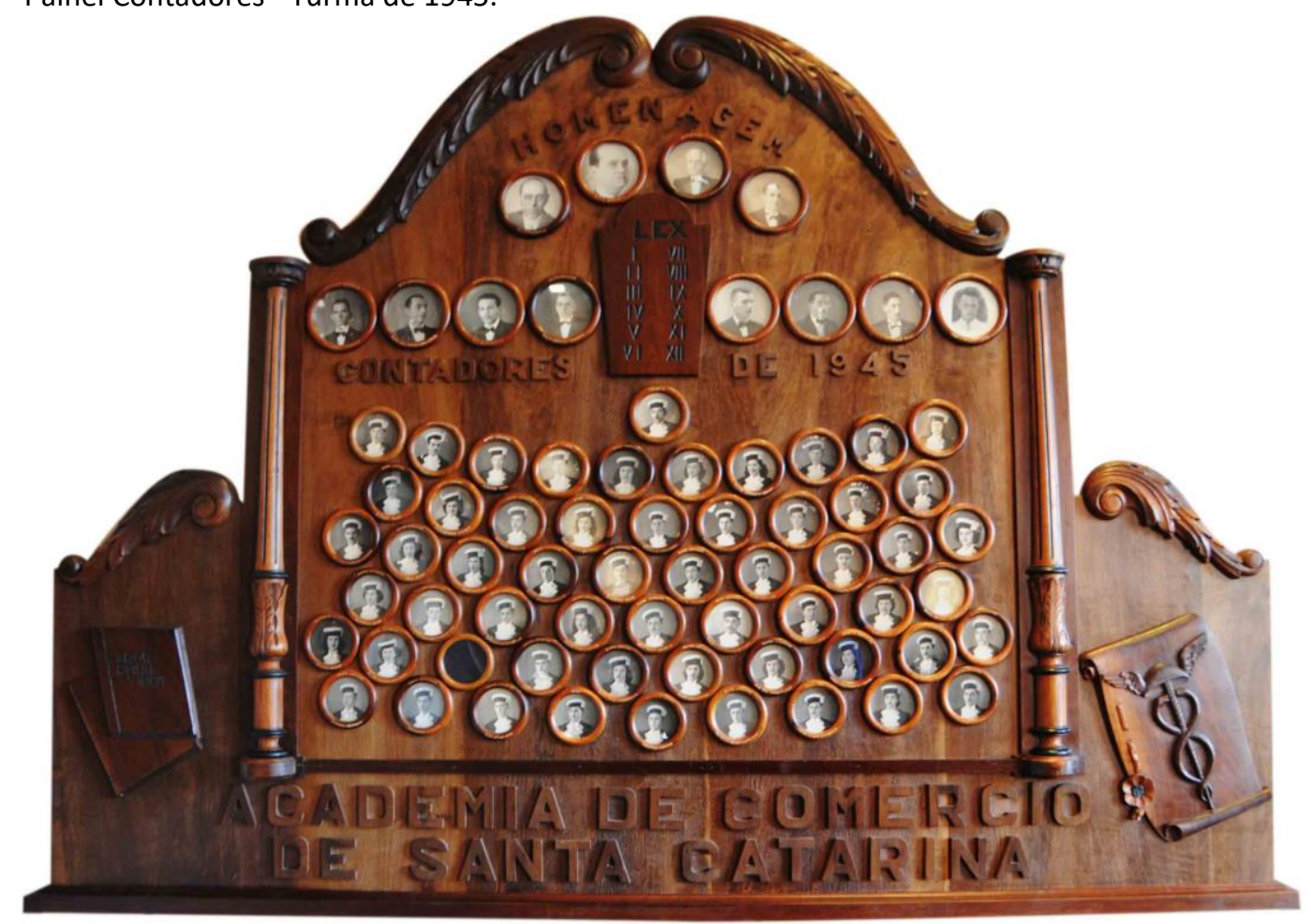

Fonte: Acervo MESC. Fotos das autoras (2017).

\footnotetext{
${ }^{7}$ Foi selecionado por Santa Catarina em sua categoria, mas não foi premiado na seleção nacional.
} 
Figura 11 - Painel Contadores - Turma de 1940. Detalhe de entalhes em que aparece a Ponte Hercílio Luz, na parte inferior do painel.

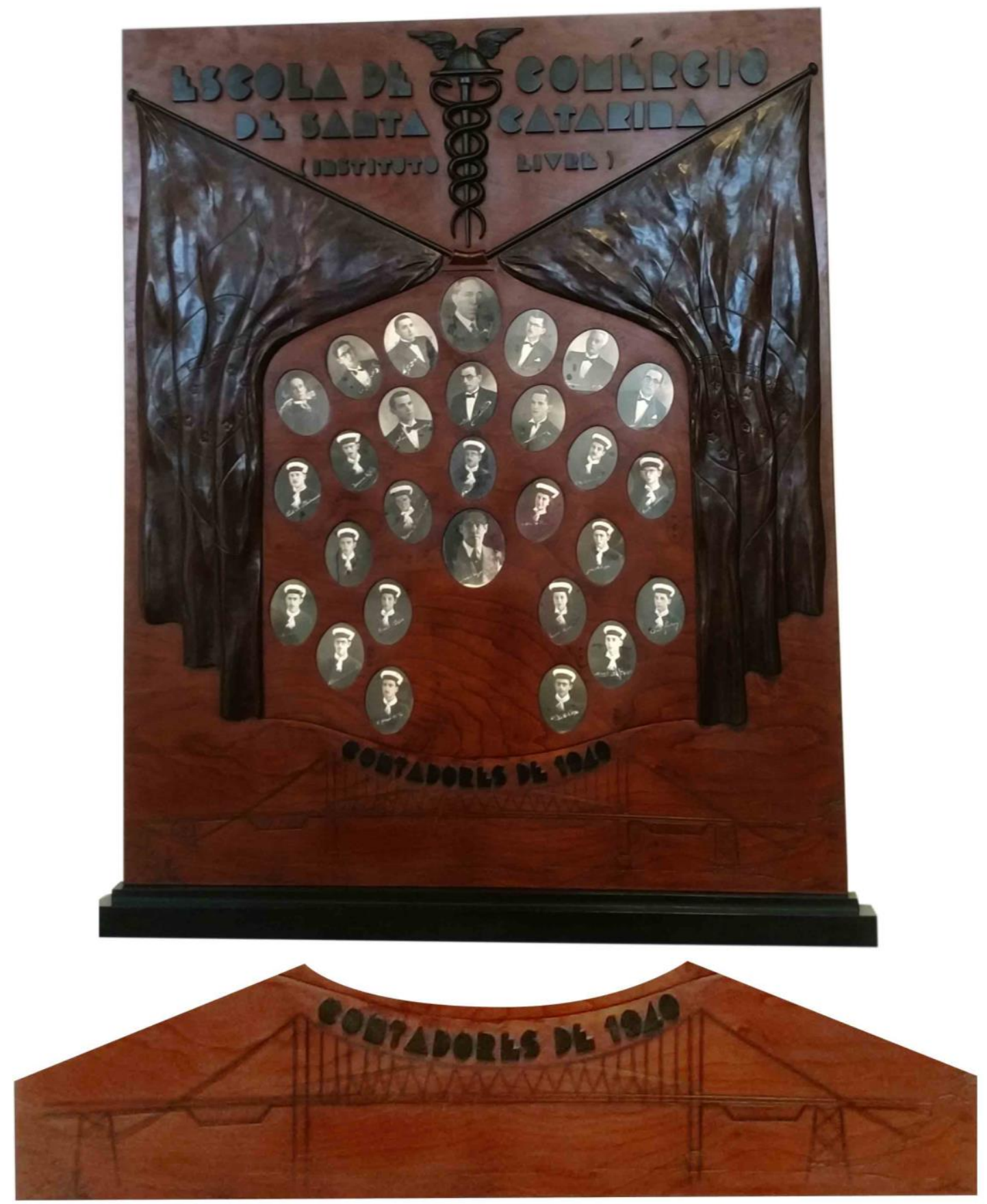

Fonte: Acervo MESC. Fotos das autoras (2017). 
Figura 12 - Painel Contadores - Turma de 1939. Detalhe de Mapa de Santa Catarina.

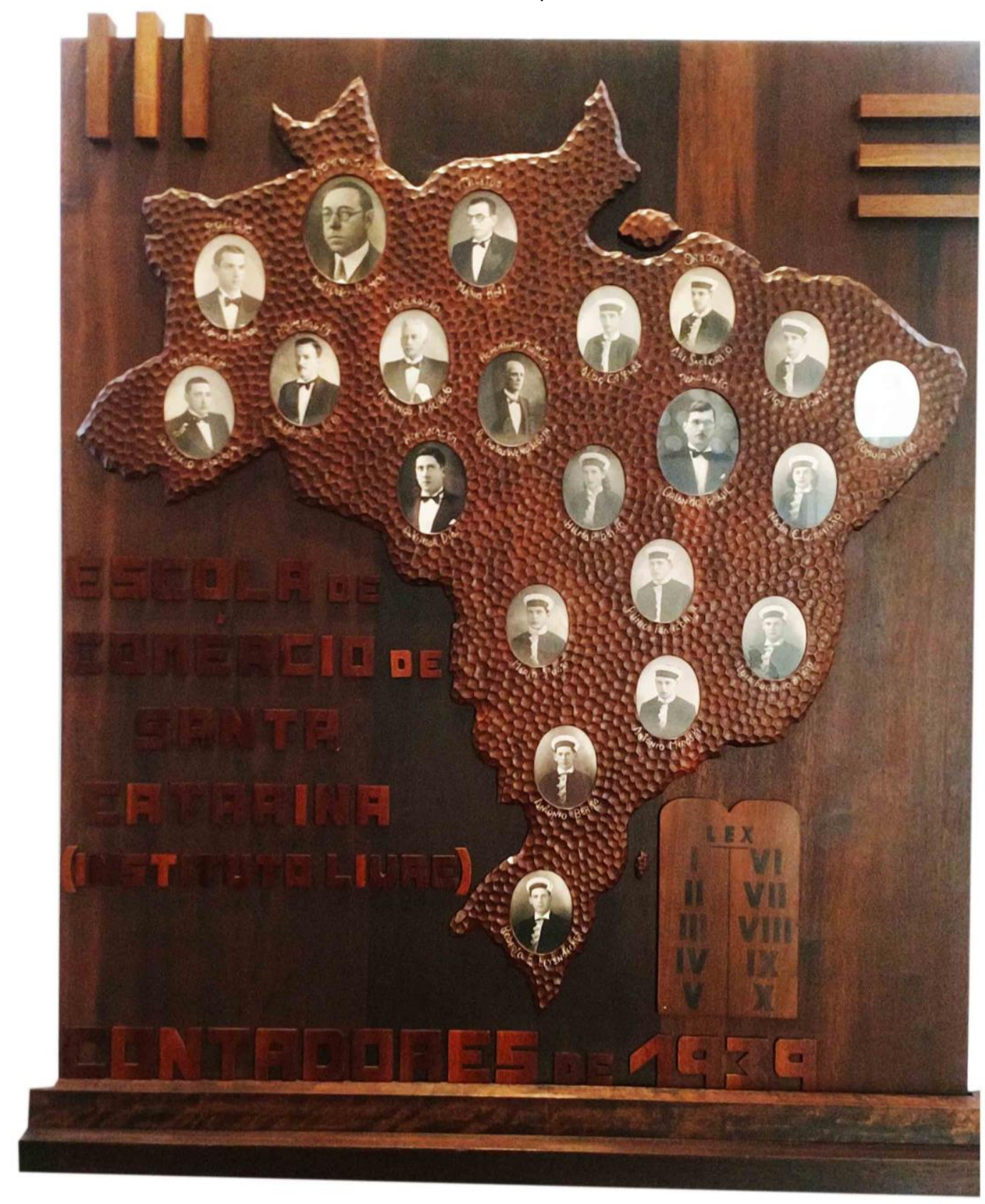

Fonte: Acervo MESC. Fotos das autoras (2017).

\section{ARQUIVOS COMO QUESTÃO DE FUTURO}

Para Georges Didi-Huberman, o arquivo é sempre "uma história em construção", pois a cada nova descoberta aparece nele como uma "brecha na história concebida", uma singularidade a qual o investigador vai unir com tudo o que já sabe, para possivelmente "produzir uma história repensada do acontecimento em questão" (2012, p. 130). Os estudos de arquivos na 
contemporaneidade precisam ter em conta sua densidade histórica, evidentemente. Giorgio Agamben (2009) diz que a contemporaneidade é uma "revenant", onde projetamos uma luz sobre o passado que o traz de volta, hoje, diferentemente. O entendimento, a partir da produção em pesquisa contemporânea, da pertinência de uma produção passada imediata, é o que podemos chamar de arqueologia imediata. O contemporâneo se constrói, não apenas na chave da emergência absoluta. Ele se constrói também pela projeção e dessa espécie de retroprojeção, já que entendemos melhor a pertinência de certas obras do passado com o olhar do presente. DidiHuberman (2012, p. 130) afirma também que "o arquivo não é nem o reflexo puro e simples do acontecimento, nem a sua pura e simples prova. Pois ele deve ser sempre elaborado mediante recortes incessantes, mediante uma montagem cruzada com outros arquivos". Em um texto bastante utilizado na área de patrimônio, chamado "O novo historicismo: ressonância e encantamento", Greenblatt (1991) define dois conceitos importantes: ressonância e encantamento. Os objetos que compõem um patrimônio precisam encontrar "ressonância" junto a seu público. Esse historiador conceitua "ressonância" e "encantamento" examinando a maneira como nossa cultura apresenta para si mesma, não os vestígios textuais de seu passado, mas os vestígios visuais e materiais que dele sobrevivem, pois, estes últimos estão colocados em exibição em museus e galerias projetados especificamente para este fim.

\footnotetext{
Por ressonância entendo o poder do objeto exibido de alcançar um mundo maior além de seus limites formais, de evocar em quem os vê as forças culturais complexas e dinâmicas das quais emergiu e das quais pode ser considerado pelo espectador como uma metáfora ou simples sinédoque (GREENBLATT, 1991, p. 250).
}

Ou seja, ressonância como o poder de evocar no espectador as forças culturais complexas e dinâmicas de onde eles emergiram. O autor define também encantamento. "Por encantamento entendo o poder do objeto exibido de pregar o espectador em seu lugar, de transmitir um sentimento arrebatador de unicidade, de evocar uma atenção exaltada" (GREENBLATT, 1991, p. 250). O encantamento tem a ver com uma espécie de veneração e tem sido mais associado com o formalismo do que com o historicismo. Costumamos venerar determinadas obras históricas, com seu passado e tradição. Uma obra de arte conhecida, como algumas obras de Van Gogh, Leonardo da Vinci, ou documentos da proclamação de independência, para ilustrar, são vistas como vestígios visuais e materiais colocados em exibição em museus e galerias projetados especificamente para 
este fim. Já museus com objetos que não valem pela sua singularidade, mas pela sua capacidade de proporcionar o conhecimento de uma manifestação social, expressiva, podem causar ressonâncias com maior intensidade pelo poder de evocar no espectador as forças culturais complexas e dinâmicas. Uma exposição ressonante, explica o autor, frequentemente distancia o espectador da celebração de objetos isolados, e o leva em direção a uma série de relações e questões sugeridas, apenas semivisíveis. E lança uma série de perguntas aplicadas ao que vemos no Museu da Escola Catarinense, ao vermos seus objetos, seus móveis, sua cultura material escolar:

\footnotetext{
Como os objetos chegaram a ser expostos? O que está em jogo na sua caracterização como "dignos de museu"? Como eram originalmente utilizados? [...] Quais os sentimentos das pessoas que originalmente seguraram esses objetos, os colecionaram, possuíram? Qual o significado de meu relacionamento com esses mesmos objetos agora que eles estão expostos aqui, neste museu, neste dia? (GREENBLATT, 1991, p. 253).
}

Os depoimentos contidos nos livros de visita do Museu da Escola Catarinense nos levam geralmente a uma ênfase maior no próprio prédio, onde se formaram muitos professores que ali retornam, ou à própria atmosfera do ambiente escolar, que exerce um efeito diferenciado em cada espectador. O elogio ao espaço físico é constante, bem como um agradecimento pelo cuidado que a Universidade e equipe do Museu tem com o espaço e a valorização da memória.

Alguns visitantes, quando entram no ambiente de imersão com os painéis de formatura, acabam por emocionar-se de tal forma que surpreende verificar o efeito na memória das pessoas. Muitos relatam fatos e histórias vivenciadas naquela época, outras pessoas buscam por familiares e/ou conhecidos que podem estar ali. Outros, mais jovens, ficam extasiados com a riqueza de detalhes dos painéis, como por exemplo os entalhes na madeira e os seus significados. Voltando à hipótese e problema deste trabalho, não resta dúvida que estes quadros indicam sentidos que os mesmos podem tomar frente às instituições escolares, e mesmo sendo considerados como fontes acessórias, possuem capacidade de contribuir para configurar a cultura e descrever subjacentes lógicas institucionais, que vão desde serem considerados como instrumentos de afirmação de determinadas identidades, como outras lógicas institucionais. Todavia, este texto apresenta uma reflexão sobre o potencial informativo dos quadros, o processo de sua recuperação, mas não avança em relação à leitura dessas obras, justamente porque se trata de uma pesquisa em estágio inicial.

O que se sabe até o momento está aqui descrito sinteticamente, esperando que o futuro 
reserve a esses painéis novas e mais completas arqueografias, reafirmando se tratar de documentos, que constituem arquivos em aberto, repletos de histórias para contar como uma questão de futuro.

\section{REFERÊNCIAS}

AGAMBEN, Giorgio. O que é contemporâneo? E outros ensaios. Chapecó: Argos, 2009.

COELHO JUNIOR, Nelson Maurilio. Relicários de um tempo: os quadros de formatura do Colégio Coração de Jesus 1922 -1929 (contribuições para o estudo da história da educação em Santa Catarina). 2013. Dissertação (Mestrado em Educação) - Centro de Ciências Humanas e da Educação, Universidade do Estado de Santa Catarina, Florianópolis, 2013. Disponível em: http://sistemabu.udesc.br/pergamumweb/vinculos/00006d/00006dc0.pdf. Acesso em: 26 jul. 2019.

CENTRO DE CIÊNCIAS JURÍDICAS (Florianópolis). Universidade Federal de Santa Catarina. Histórico. [201-]. Disponível em: http://ccj.ufsc.br/historico/. Acesso em: 30 jul. 2019.

DERRIDA, Jacques. Mal de arquivo: uma impressão freudiana. Rio de Janeiro: Relume Dumará, 2001.

DERRIDA, Jacques. Pensar em não ver: escritos sobre as artes do visível (1979-2004). Florianópolis: UFSC, 2012.

DIDI-HUBERMAN, Georges. Imagens apesar de tudo. Lisboa: KKYM, 2012.

FARIA, Juliano Espezim Soares; SANTOS, Ademir Valdir dos; VALLE, Ione Ribeiro. A Matemática como disciplina da Academia de Comércio de Santa Catarina. Alexandria, [s.I.], v. 7, n. 2, p. 3-21, nov. 2014. Disponível em:

https://periodicos.ufsc.br/index.php/alexandria/article/viewFile/38213/29117. Acesso em: 26 jul. 2019.

GREENBLATT, Stephen. O novo historicismo: ressonância e encantamento. Revista Estudos Históricos, Rio de Janeiro, v. 4, n. 8, p. 244-261, dez. 1991. Disponível em:

http://bibliotecadigital.fgv.br/ojs/index.php/reh/article/view/2323/1462. Acesso em: 26 jul. 2019.

HISTÓRIA DA CONTABILIDADE NO BRASIL. In: WIKIPÉDIA: a enciclopédia livre. [São Francisco, CA: Wikipedia Foundation, 2019]. Disponível em:

https://pt.wikipedia.org/wiki/História_da_contabilidade_no_Brasil. Acesso em 29 jul. 2019.

LE GOFF, Jacques. História e Memória. Campinas: Unicamp, 1990. 
PETRY, Eduardo. Academia de Comércio de Santa Catarina. In: PETRY, Eduardo. Blog Santa Catarina antiga, [s.l.], 30 maio 2013. Disponível em:

http://santacatarinaantiga.blogspot.com.br/2013/05/academia-de-comercio-de-santacatarina.html. Acesso em: 26 jul. 2019.

SANSON, João Rogério; NICOLAU, José Antônio. Do ensino de técnicas comerciais ao ensino de economia em Santa Catarina. Análise: Revista de Administração da PUCRS, Porto Alegre, v. 17, n. 2, p. 297-312, jul./dez. 2006. Disponível em:

http://revistaseletronicas.pucrs.br/ojs/index.php/face/article/viewFile/311/248. Acesso em: 26 jul. 2019.

SANTA CATARINA. Universidade do Estado de Santa Catarina. Governo de Santa Catarina. Escola Normal Catharinense. 2014. Disponível em: http://www1.udesc.br/?id=2035. Acesso em: 31 jul. 2019.

SOUZA, Rosa Fátima de. História da cultura material escolar: um balanço inicial. In: BENCOSTA, Marcus Levy (org.). Culturas escolares, saberes e práticas educativas: itinerários históricos. São Paulo: Cortez, 2007. p. 152-178.

VIEIRA, Amazile de Hollanda. O Instituto Polytechnico no contexto sócio-cultural catarinense. Florianópolis: A\&P, 1986.

WERLE, Flavia Obino Corrêa. Ancorando quadros de formatura na história institucional. In: REUNIÃO ANUAL DA ANPED, 28., 2005, Caxambu. Anais [...]. Caxambu: ANPED, 2006. Disponível em: http://www.anped.org.br/28/textos/GT02/GT02-322--Int.rtf. Acesso em: 26 jul. 2019.

WERLE, Flavia Obino Corrêa. História das instituições escolares: de que se fala? In: LOMBARDI, José Claudinei, NASCIMENTO, Maria Isabel (org.). Fontes, história e historiografia da educação.

Campinas, SP: Autores Associados, 2004. p. 13-35. 